\title{
Erratum to: Vasodilator Therapy: Nitrates and Nicorandil
}

\author{
Jason M. Tarkin ${ }^{1} \cdot$ Juan Carlos Kaski $^{2}$
}

Published online: 14 August 2017

(C) The Author(s) 2017. This article is an open access publication

\section{Erratum to: Cardiovasc Drugs Ther (2016) 30:367-378 https://doi.org/10.1007/s10557-016-6668-z}

The article entitled Vasodilator Therapy: Nitrates and Nicorandil, written by Jason M. Tarkin and Juan Carlos Kaski, was originally published Online First without open access. After publication in volume 30, issue 4, pages 367378, the author decided to opt for Open Choice and to make the article an open access publication. Therefore, the copyright of the article has been changed to $(\subset)$ The Author(s) [2016] and the article is forthwith distributed under the terms of the Creative Commons Attribution 4.0 International
License (http://creativecommons.org/licenses/by/4.0/), which permits use, duplication, adaptation, distribution and reproduction in any medium or format, aslong as you give appropriate credit to the original author(s) and the source, provide a link to the Creative Commons license, and indicate if changes were made.

Open Access This article is distributed under the terms of the Creative Commons At tribution 4.0 International License (http:/ /creativecommons.org/licenses/by/4.0/), which permits unrestricted use, distribution, and reproduction in any medium, provided you give appropriate credit to the original author(s) and the source, provide a link to the Creative Commons license, and indicate if changes were made.

The online version of the original article can be found at http://dx.doi.org/10. 1007/s10557-016-6668-Z

Juan Carlos Kaski

jkaski@sgul.ac.uk

1 Division of Cardiovascular Medicine, University of Cambridge, Box 110, ACCI, Addenbrooke's Hospital, Cambridge CB2 QQ, UK

2 Cardiovascular and Cell Sciences Research Institute, St George's, University of London, Cranmer Terrace, Tooting, London SW17 ORE, UK 